\title{
Protein concentration and enzyme activities of fresh and frozen-thawed Persian sturgeon, Acipenser persicus (Borodin, 1897) semen
}

\author{
Mohammad Sadegh Aramli • Mohammad Reza Kalbassi • \\ Rajab Mohammad Nazari
}

Received: 7 September 2013/ Accepted: 16 December 2013/Published online: 18 March 2014

(C) The Author(s) 2014. This article is published with open access at Springerlink.com

\begin{abstract}
The membrane integrity of fish spermatozoa can be compromised after exposure to a freeze-thaw cycle, resulting in leakage of proteins in the seminal fluid. In the present work, the total protein concentration (TP) and enzyme activities of acid phosphatase (AcP), lactate dehydrogenase (LDH), arylsulfatase (AS), $\beta$ - $N$ acetylglucosaminidase ( $\beta$ - $N$-AGase) were measured in seminal plasma of fresh and freeze-thawed semen of Persian sturgeon (Acipenser persicus Borodin). The enzyme activity of fresh and frozen-thawed seminal plasma was as: AcP $(0.59 \pm 0.035$ and $9.89 \pm 0.81)$, LDH $(484.4 \pm 27.3$ and $6,262.7 \pm 263.2)$, AS $(169.1 \pm 44.4$ and $699.6 \pm 25.1), \beta$ - $N$-AGase $(36.31 \pm 2.25$ and $70.7 \pm 2.24)$, respectively, in fresh and freeze-thawed sperm. The TP semen content in fresh semen was $0.28 \pm 0.031$ and in frozen-thawed was $1.68 \pm 0.1$. The results indicate that TP concentration and activities of AcP, LDH, AS, and $\beta$ - $N$-AGase were significantly higher in frozen-thawed seminal plasma. For this reason, these molecules may be used as markers for estimation of membrane damage of spermatozoa exposed to freeze-thaw cycle.
\end{abstract}

Keywords Protein content $\cdot$ Enzyme activities $\cdot$ Seminal plasma $\cdot$ Frozen-thaw cycle $\cdot$ A. persicus

\section{Background}

Sturgeons are considered to be "living fossils" (Bemis et al. 1997). Their evolutionary history dates back to the early Jurassic period (approximately 100-200 million years ago). The Caspian Sea is home to the four commercial species of sturgeon, including the Persian sturgeon, Acipenser persicus Borodin (Khodorevskaya et al. 1997). However, their populations are declining due to excessive fishing for meat and caviar production, habitat destruction, and water pollution (Billard and Lecointre 2001). Thus, there has been an increased demand for information about all aspects of sturgeon reproduction (Billard and Lecointre 2001; Baker et al. 2005; Aramli et al. 2013a).

M. S. Aramli ( $\varangle) \cdot$ M. R. Kalbassi · R. M. Nazari

Young Researchers and Elites Club, Ardabil Branch, Islamic Azad University, P.O. Box 31567-56157,

Ardabil, Iran

e-mail: msaramli@gmail.com; m.s.aramli@iauardabil.ac.ir

M. S. Aramli · M. R. Kalbassi · R. M. Nazari

Rajaee Sturgeon Propagation Center, P.O. Box 833, Sari, Mazandaran, Iran

M. R. Kalbassi

Aquaculture Department, Faculty of Marin Sciences, Tarbiat Modares University, P.O. Box 46414-356,

Noor, Mazandaran, Iran 
Studies of the usefulness of biochemical indicators as estimators of semen quality generally focus on parameters measured from plasma from fresh semen and supernatants of cryopreserved semen. Enzyme activities are measured in sperm extracts or in the supernatants after long- and short-term storage (Ciereszko 2008). Assessment of the composition and functions of proteins and enzymes provides insights into the spermatozoa motility and fertilizing abilities that remain after processing. Identifying optimum processing techniques and storage conditions will improve artificial reproduction programs and germplasm resource conservation procedures.

Seminal plasma proteins help protect spermatozoa during storage in the reproductive organ, whereas all semen proteins contribute to the swimming and fertilizing abilities of sperm ( $\mathrm{Li}$ et al. 2008). Compared with what is known about mammalian semen, the enzymology of fish gametes is poorly understood. However, activities of aspartate aminotransferase, lactate dehydrogenase (LDH), acid phosphatase (AcP), $\beta$ - $N$-acetylglucosaminidase ( $\beta$ - $N$-AGase), anti-proteinase, and arylsulfatase (AS) in fish semen have been studied previously (Schemehl et al. 1987; McNiven et al. 1992; Ciereszko and Dabrowski 1994; Piros et al. 2002; Sarosiek et al. 2004, 2006; Aramli et al. 2013b).

In contrast to gametes from teleost fish, sturgeon sperm are characterized by the presence of an acrosome (Jamieson 1991) and oocytes contain multiple micropyles (Cherr and Clark 1985). Previous studies of the sturgeon acrosome focused on acrosin-like activity of the sperm (Ciereszko and Dabrowski 1994; Ciereszko et al. 1996, 2000) and activities of AS and $\beta$ - $N$-AGase (Piros et al. 2002). The acrosomal enzymes of sturgeon may be important in certain situations. For example, prolonged contact of oocytes with water may lead to micropyle obstruction by the jelly coat layer, thus the enzymes may be needed to increase fertilization ability (Ciereszko et al. 2000).

To our knowledge, no data are available on the activity of enzymes in A. persicus semen. This study was designed to measure the enzymatic activity of AcP, LDH, AS, and $\beta$ - $N$-AGase and the total protein concentration (TP) in Persian sturgeon semen and to determine the range of enzymatic activity present in the seminal plasma of fresh semen and supernatants obtained after freezing-thawing.

\section{Methods}

Fish, spermiation induction and sampling

Eight wild-caught Persian sturgeon $(143.38 \pm 5.47 \mathrm{~cm}$ total length and $15.81 \pm 0.57 \mathrm{~kg}$ mean body weight) were captured (using gillnets, length $18 \mathrm{~m}$, width $5.4 \mathrm{~m}$, mesh size $15 \mathrm{~cm}$ ) from the southwestern part of the Caspian Sea and transported to the Rajaee Sturgeon Hatchery Center (Sari, Mazandaran, Iran; Lat $36^{\circ} 37^{\prime} \mathrm{N}$, Long $53^{\circ} 05^{\prime} \mathrm{E}$ ) between March and April 2011. To induce spermiation, fish were injected with luteinizing hormone-releasing hormone agonists at a dosage of $5 \mu \mathrm{g} / \mathrm{kg}$ body weight (Nazari et al. 2010; Aramli et al. 2014) by placing the syringe in the muscles between the dorsal and lateral scutes. Temperature of the water during the experiment was between 12.5 and $14.0^{\circ} \mathrm{C}$. Spermiation occurred within $12 \mathrm{~h}$ after hormonal injection, and followed by subsequent stripping at 17 and $22 \mathrm{~h}$ after hormone injection. Semen was collected using a syringe with attached rigid tubing inserted into the urogenital opening. Semen samples (three samples per male) were taken from each of the eight treated males equally during experiment.

Preparation of seminal plasma and supernatants

Semen was stored in a glass tube on ice $\left(4^{\circ} \mathrm{C}\right)$ during transportation to the laboratory (for up to $3 \mathrm{~h}$ ). Seminal plasma from fresh semen was separated immediately from spermatozoa by centrifugation $(5,000 \mathrm{rpm}$ for $10 \mathrm{~min}$, Labnet Spectrafuge $16 \mathrm{M}$, Woodbridge, NJ, USA). A part of the semen, which was transferred into $1.5 \mathrm{~mL}$ microtubes, was frozen at $-79^{\circ} \mathrm{C}$ for 1 day to evaluate the extent of leakage of enzymes that occurs after damage to sperm caused by freezing and thawing. Semen was thawed at room temperature, centrifuged and the supernatant was used for enzyme analysis. We did not use any cryoprotectants or extenders in this study. 
Analytical procedures

Acid phosphatase activity was determined using $5 \mathrm{mM}$ p-nitrophenylphosphate in $20 \mathrm{mM}$ citrate buffer, $\mathrm{pH} 5$ (Glogowski et al. 1996). After $30 \mathrm{~min}$ of incubation at $37^{\circ} \mathrm{C}$, the reaction was stopped with $0.1 \mathrm{M} \mathrm{NaOH}$, and absorbance at $410 \mathrm{~nm}$ was measured (Glogowski et al. 1996). Lactate dehydrogenase activity was measured using the UV method with pyruvate and NADH. The reaction mixture consisted of $1.6 \mathrm{mM}$ sodium pyruvate and $0.2 \mathrm{mM} \mathrm{NADH}$ in $80 \mathrm{mM}$ Tris- $\mathrm{HCl}$ buffer containing $200 \mathrm{mM} \mathrm{NaCl}, \mathrm{pH}$ 7.3. Absorbance at $339 \mathrm{~nm}$ was measured. The duration of incubation was $5 \mathrm{~min}$ at $30^{\circ} \mathrm{C}$ (Vassault 1983). Activity of AS was determined using $0.2 \mathrm{ml} 20 \mathrm{mM}$ p-nitrocatechol sulfate as a substrate in $0.5 \mathrm{M}$ sodium acetate buffer, $\mathrm{pH}$ 4.9. After 30 min of incubation at $37{ }^{\circ} \mathrm{C}$, the reaction was stopped with $2.5 \mathrm{ml} 1 \mathrm{M} \mathrm{NaOH}$, and absorbance at $515 \mathrm{~nm}$ was measured (Yang and Srivastava 1974). Activity of $\beta$ - $N$-AGase was measured using $0.5 \mathrm{mM}$ p-nitrophenyl $\beta$ - $N$-glucosaminide as a substrate in $0.1 \mathrm{M}$ citrate buffer, $\mathrm{pH}$ 5.0. After $60 \mathrm{~min}$ of incubation at $37{ }^{\circ} \mathrm{C}$, the reaction was stopped with $0.1 \mathrm{M} \mathrm{NaOH}$, and absorbance at $410 \mathrm{~nm}$ was measured (Jauhiainen and VanhaPerttula 1986). Total protein concentration was measured following Lowry et al. (1951), with absorbance measured at $546 \mathrm{~nm}$ and $37^{\circ} \mathrm{C}$.

Statistical analysis

Data were analyzed using one-way analysis of variance followed by Duncan's multiple range test. $P<0.05$ was considered to be statistically significant. All data are expressed as mean \pm standard error.

\section{Results and discussion}

Table 1 shows the TP and enzymatic activities from Persian sturgeon semen. AS, $\beta$ - $N$-AGase, LDH, and AS activity and protein were detected in both seminal plasma of fresh and frozen-thawed semen. Almost all parameters analyzed in seminal plasma after freezing-thawing were statistically higher than those in the seminal plasma of fresh semen.

Seminal plasma proteins play a key role in prolongation of sperm viability in teleost fish (Lahnsteiner et al. 2004). Thus, a better understanding of the enzyme activities in seminal plasma and spermatozoa is necessary to identify proteins that can be used as indicators of damage to sturgeon semen. Currently, little is known about the proteins present in the seminal plasma of sturgeons. However, specific proteins should exist in the seminal plasma to protect the spermatozoa. Several studies have been conducted to measure the protein concentrations in the seminal plasma of different sturgeon species (Table 2). Similar to most sturgeons, the seminal plasma of Persian sturgeon in contrast to that of higher vertebrates is characterized by much lower protein concentration.

AS and $\beta$ - $N$-AGase are among the key enzymes localized within the mammalian acrosome that play a pivotal role in penetration of the oocyte (Nikolajczyk and O'Rand 1992; Brandon et al. 1997). In this study, we found that these two enzymes are present in the semen of Persian sturgeon. Their presence was expected due to the presence of the active acrosome in sturgeon semen. Previous results indicated that activities of AS and $\beta$ - $N$-AGase differed between seminal plasma of fresh and frozen-thawed semen, with greater activity in the latter (Tables 1, 2). In seminal plasma samples of different types of sturgeon, higher concentrations of these enzymes also were present in the supernatant of the frozen-thawed sperm samples (Table 2). These results indicate that these enzymes are localized in both seminal plasma of fresh and frozen-thawed semen (Piros et al. 2002; Sarosiek et al. 2004).

Another enzyme present in the seminal plasma of sturgeon is AcP (Piros et al. 2002). The concentration of this enzyme was very low in the seminal plasma of fresh semen but significantly higher in the supernatant of frozen-thawed semen (Table 2). Sarosiek et al. (2006) reported the existence of at least two forms of AcP with molecular weights of 39 and $19 \mathrm{kDa}$ in the semen of Russian sturgeon. Acid phosphatase role in sturgeon reproduction is unknown. In mammals, AcP has an important role in phosphorylation and dephosphorylation reactions during sperm capacitation, hyperactivation, and acrosome reaction as well as sperm-egg fusion (Urner and Sakkas 2003). Lactate dehydrogenase is an enzyme that helps to produce energy. In fact, formation of lactate allows glycolysis to proceed, in the absence of oxygen, for another cycle of the reaction catalyzed by 
Table 1 Protein concentration and enzymatic activities in seminal plasma of fresh and freeze-thawed semen of Persian sturgeon $(n=8$ and three samples per male)

\begin{tabular}{lcr}
\hline & Fresh & Freeze-thawed \\
\hline Protein concentration $\left(\mathrm{g} \mathrm{l}^{-1}\right)^{*}$ & $0.28 \pm 0.031$ & $1.68 \pm 0.1$ \\
Lactate dehydrogenase $\left(\mathrm{U} \mathrm{l}^{-1}\right)^{*}$ & $484.4 \pm 27.3$ & $6,262.7 \pm 263.2$ \\
Acid phosphatase $\left(\mathrm{U} \mathrm{l}^{-1}\right)^{*}$ & $0.59 \pm 0.035$ & $9.89 \pm 0.81$ \\
Arylsulfatase $\left(\mathrm{U} \mathrm{l}^{-1}\right)^{*}$ & $169.1 \pm 44.4$ & $699.6 \pm 25.1$ \\
$\beta$ - $N$-acetylglucosaminidase $\left(\mathrm{U} \mathrm{l}^{-1}\right)^{*}$ & $36.31 \pm 2.25$ & $70.7 \pm 2.24$ \\
\hline
\end{tabular}

* Significant different between seminal plasma of fresh and freeze-thawed semen

Table 2 Comparison of protein content and enzyme activities of seminal plasma from different sturgeon species

\begin{tabular}{|c|c|c|c|c|c|c|c|}
\hline Species & Semen type & $\mathrm{TP}\left(\mathrm{g} \mathrm{dl}^{-1}\right)$ & $\mathrm{AS}\left(\mathrm{U}^{-1}\right)$ & $\begin{array}{l}\beta \text {-N-AGase } \\
\left(\mathrm{U}^{-1}\right)\end{array}$ & $\operatorname{AcP}\left(\mathrm{U}^{-1}\right)$ & $\mathrm{LDH}\left(\mathrm{U}^{-1}\right)$ & Authors \\
\hline \multirow[t]{4}{*}{ Sterlet } & Fresh & 0.5 & 207.0 & 53.68 & 1.85 & 761.7 & \multirow{2}{*}{$\begin{array}{l}\text { Piros et al. } \\
\quad(2002)^{\mathrm{a}}\end{array}$} \\
\hline & $\begin{array}{l}\text { Frozen- } \\
\text { thawed }\end{array}$ & 1.33 & 760.2 & 79.09 & 7.89 & $8,803.0$ & \\
\hline & Fresh & 0.24 & 54.1 & 23.65 & 0.9 & 71 & \multirow{2}{*}{$\begin{array}{l}\text { Piros et al. } \\
(2002)^{\mathrm{b}}\end{array}$} \\
\hline & $\begin{array}{l}\text { Frozen- } \\
\text { thawed }\end{array}$ & 1.6 & 937.1 & 44.59 & 5.82 & $9,493.0$ & \\
\hline \multirow{4}{*}{$\begin{array}{l}\text { Siberian } \\
\text { sturgeon }\end{array}$} & Fresh & 0.58 & 684.3 & 16.39 & 1 & 278.4 & \multirow{2}{*}{$\begin{array}{l}\text { Piros et al. } \\
\quad(2002)^{\mathrm{c}}\end{array}$} \\
\hline & $\begin{array}{l}\text { Frozen- } \\
\text { thawed }\end{array}$ & 4.33 & $2,720.5$ & 61.59 & 20.6 & $4,420.0$ & \\
\hline & Fresh & 0.57 & 638.5 & 20.49 & 1.21 & 400.9 & \multirow{2}{*}{$\begin{array}{l}\text { Piros et al. } \\
\quad(2002)^{\mathrm{d}}\end{array}$} \\
\hline & $\begin{array}{l}\text { Frozen- } \\
\text { thawed }\end{array}$ & 4.40 & $2,993.9$ & 67.28 & 23.81 & $7,217.3$ & \\
\hline \multirow[t]{2}{*}{ Stellate } & Fresh & 0.3 & & & & & \multirow{2}{*}{$\begin{array}{r}\text { Li et al. } \\
\text { (2011) }\end{array}$} \\
\hline & $\begin{array}{l}\text { Frozen- } \\
\text { thawed }\end{array}$ & & & & & & \\
\hline \multirow{2}{*}{$\begin{array}{l}\text { Russian } \\
\text { sturgeoon }\end{array}$} & Fresh & 0.6 & & & & & \multirow{2}{*}{$\begin{array}{l}\text { Li et al. } \\
\quad(2011)\end{array}$} \\
\hline & $\begin{array}{l}\text { Frozen- } \\
\text { thawed }\end{array}$ & & & & & & \\
\hline \multirow{2}{*}{$\begin{array}{l}\text { Persian } \\
\text { sturgeon }\end{array}$} & Fresh & $0.28 \pm 0.031$ & $169.1 \pm 44.4$ & $36.31 \pm 2.25$ & $0.59 \pm 0.035$ & $484.4 \pm 27.3$ & \multirow[t]{2}{*}{ Present study } \\
\hline & $\begin{array}{l}\text { Frozen- } \\
\text { thawed }\end{array}$ & $1.68 \pm 0.1$ & $699.6 \pm 25.1$ & $70.7 \pm 2.24$ & $9.89 \pm 0.81$ & $6,262.7 \pm 263.2$ & \\
\hline \multicolumn{8}{|c|}{$T P$ total protein, $A S$ arylsulfatase, $\beta$ - $N$-AGase $\beta$ - $N$-acetylglucosaminidase, $A c P$ acid phosphatase, $L D H$ lactate dehydrogenase } \\
\hline \multicolumn{8}{|c|}{${ }^{a}$ Fish captured from the Danube River } \\
\hline \multicolumn{8}{|c|}{ b Fish captured from the Dolna Odra Power Plant } \\
\hline \multicolumn{8}{|c|}{ c 1 st Semen collection } \\
\hline d 2 nd Seme & llection & & & & & & \\
\hline
\end{tabular}

GAPDH (Miki 2007). Like the other enzymes investigated in this paper, LDH activity was higher in the supernatant of frozen-thawed semen than in fresh samples. Piros et al. (2002) also reported a significant increase in LDH in the supernatant of frozen-thawed semen of Siberian sturgeon and sterlet (Table 2). They suggested that the LDH likely originated from spermatozoa and the disruption of the energy supply during cryopreservation, which subsequently affects sperm motility.

According to the data presented in Tables 1 and 2, the activities of all enzymes were much higher after freezing-thawing and significantly higher in the supernatant of frozen-thawed semen. For this reason, they are good potential candidates as markers of cryoinjury, as was previously described for teleost fish (Glogowski et al. 1996; Lahnsteiner et al. 1996; Babiak et al. 1997). Lactate Dehydrogenase and AcP activities may be indicators of damage to the plasmolemma and the midpiece area of the sperm structure, whereas AS and $\beta-N$ AGase activities may be useful indices of damage to the acrosome in cryopreserved semen. However, further 
studies are necessary to explore the roles of these enzymes in the semen structure of Persian sturgeon. In conclusion, the results contribute data on the enzymatic properties of semen of Persian sturgeon. These data are critical for the development of optimal diluents for the long- and short-term storage of sperm in the endangered species.

Acknowledgments This study was financed by Tarbiat Modares University, Tehran, Iran. The authors would like to thank all of the technical staff of Rajaee Sturgeon Hatchery Center (Sari, Iran) for their help and support during this experiment.

Conflict of interest The authors declare that they have no conflict of interests.

Authors' contributions MRK and MSA participated in the design of the study. MSA and RMN carried out the experiment and performed thestatistical analysis. MSA and MRK participated in the discussion and corrected the manuscript. All authors read andapproved the final manuscript.

Open Access This article is distributed under the terms of the Creative Commons Attribution License which permits any use, distribution, and reproduction in any medium, provided the original author(s) and the source are credited.

\section{References}

Aramli MS, Kalbassi MR, Nazari RM (2013a) Selected biochemical parameters in plasma of blood and semen of Persian sturgeon, Acipenser persicus. Comp Clin Pathol. doi:10.1007/s00580-013-1769-6

Aramli MS, Kalbassi MR, Nazari RM (2013b) Spermatozoa and seminal plasma enzyme activity in Persian sturgeon, Acipenser persicus, in relation to short-term storage. Aqua Res. doi:10.1111/are.12349

Aramli MS, Kalbassi RM, Nzari RM (2014) Sex steroid levels of Persian sturgeon, Acipenser persicus, Borodin, 1897, males in negative and positive responding to LH-RH-analogue. J Appl Ichthyol 30(1):18-19

Babiak I, Glogowski J, Luczynski MJ, Luczynski M (1997) Effect of individual male variability on cryopreservation of northern pike, Esox lucius L., sperm. Aquacult Res 28:191-197

Baker DW, Wood AM, Litvak MK, Kieffer JD (2005) Hematology of juvenile Acipenser oxyrinchus and Acipenser brevirostrum at rest following forced activity. J Fish Biol 66:208-221

Bemis E, Findeis E, Grande L (1997) An overview of Acipenseriformes. In: Birstein VJ, Waldman JR, Bemis W, Kluwer E (eds) Sturgeon biodiversity and conservation. Academic Publishing, Dordrecht, pp 25-71

Billard R, Lecointre G (2001) Biology and conservation of sturgeon and paddlefish. Rev Fish Biol Fish 10:355-392

Brandon CI, Srivastava PN, Heusner GL, Fayer-Hosken RA (1997) Extraction and quantification of acrosin, $\beta N$-acetylglucosaminidase, and arylsulfatase-A from equine ejaculated spermatozoa. J Exp Zool 279:301-308

Cherr GN, Clark WNJR (1985) Gamete interaction in the white sturgeon, Acipenser transmontanus: a morphological and physiological review. Environ Biol Fish 14:11-22

Ciereszko A (2008) Chemical composition of seminal plasma and its physiological relationship with sperm motility, fertilizing capacity and cryopreservation success in fish. In: Alavi SMH, Cosson J, Coward K, Rafiee (eds) Fish spermatology. Alpha Science Ltd, Oxford, pp 215-240

Ciereszko A, Dabrowski K (1994) Relationship between biochemical constituents of fish semen and fertility: the effect of shortterm storage. Fish Physiol Biochem 12:357-367

Ciereszko A, Dabrowski K, Ochkur SI (1996) Characterization of acrosin-like activity of lake sturgeon (Acipenser fulvescens) spermatozoa. Mol Reprod Dev 45:72-77

Ciereszko A, Dabrowski K, Mims SD, Glogowski J (2000) Characteristics of sperm acrosin-like activity of paddlefish (Polyodon spathula Walbaum). Comp Biochem Physiol 125(B):197-203

Glogowski J, Babiak I, Goryczko K, Dobosz S (1996) Activity of aspartate aminotransferase and acid phosphatase in cryopreserved trout semen. Reprod Fert Dev 8:1179-1184

Jamieson BGM (1991) Fish evolution and systematics: evidence from spermatozoa. Cambridge University Press, Cambridge, p 319

Jauhiainen A, Vanha-Perttula T (1986) $\beta$ - $N$-acetylglucosaminidase in the reproductive organs and seminal plasma of the bull. J Reprod Fertil 76:239-250

Khodorevskaya RP, Dovgopol GF, Zhuravleva OL, Vlasenko AD (1997) Present status of commercial stocks of sturgeons in the Caspian Sea basin. Environ Biol Fishes 48:209-220

Lahnsteiner F, Berger B, Weismann T, Patzner R (1996) The influence of various cryoprotectants on semen quality of the rainbow trout (Oncorhynchus mykiss) before and after cryopreservation. J Appl Ichtyol 12:99-106

Lahnsteiner F, Mansour N, Berger B (2004) Seminal plasma prolong the viability of rainbow trout (Oncorhynchus mykiss) Spermatozoa. Theriogenology 62:801-808

Li P, Hulak M, Linhart O (2008) Sperm proteins in teleostean and chondrostean (sturgeon) fishes. Fish Physiol Biochem 35:567-581

Li P, Rodina M, Hulak M, Li ZH, Linhart O (2011) Spermatozoa concentration, seminal plasma composition and their physiological relationship in the endangered stellate sturgeon (Acipenser stellatus) and Russian sturgeon (Acipenser gueldenstaedtii). Reprod Domest Anim 46:247-252

Lowry OH, Rosebrough NJ, Farr AL, Raudall RJ (1951) Protein measurement with folin-phenol reagent. J Biol Chem 193:265-275 
McNiven MA, Gallant RK, Richardson GF (1992) In vitro methods of assessing the viability of rainbow trout spermatozoa. Theriogenology 38:679-686

Miki K (2007) Energy metabolism and sperm function. Soc Reprod Fert Suppl 65:309-325

Nazari RM, Modanloo M, Ghomi MR, Ovissipor MR (2010) Application of synthetic hormone LHRH-A 2 on the artificial propagation of Persian sturgeon Acipenser persicus. Aquacult Int 18:837-841

Nikolajczyk BS, O'Rand MG (1992) Characterization of rabbit testis $\beta$-galactosidase and arylsulfatase purification and localization in spermatozoa during the acrosome reaction. Biol Reprod 46:366-378

Piros B, Glogowski J, Kolman R, Rzemieniecki A, Domagala J, Horvath A, Urbanyi B, Ciereszko A (2002) Biochemical characterization of Siberian sturgeon, Acipenser baeri and sterlet, Acipenser ruthenus, seminal plasma and spermatozoa. Fish Physiol Biochem 26:289-295

Sarosiek B, Ciereszko A, Kolman R, Glogowski J (2004) Characteristics of arylsulfatase in Russian sturgeon (Acipenser gueldenstaedtii) semen. Comp Biochem Physiol 139B:517-579

Sarosiek B, Wysocka J, Wysocki P, Kowalski R, Glogowski J (2006) Characteristics of acid phosphatase from Russian sturgeon (Acipenser gueldenstaedtii) spermatozoa. J Appl Ichthyol 22:375-379

Schemehl MK, Graham EF, Erdhal DA (1987) Chemical constituents of trout seminal plasma and spermiduct tissue from rainbow trout Salmo gairdneri (Richardson). Fish Physiol Biochem 1:55-61

Urner F, Sakkas D (2003) Protein phosphorylation in mammalian spermatozoa. Reproduction 125:17-26

Vassault A (1983) Lactate dehydrogenase. UV-method with pyruvate and NADH. In: Bergmeyer HU (ed) Methods in enzymatic analysis, vol 3. Verlag Chemie, Weinheim, pp 118-126

Yang Ch-H, Srivastava PN (1974) Purification and properties of arylsulfatases from rabbit sperm acrosomes. Proc Soc Exp Biol Med 145:721-725 